\title{
Optimasi Pemisahan Lignin Ampas Tebu Dengan Menggunakan Natrium HIDROKSIDA
}

\author{
${ }^{1}$ Rini Setiati, ${ }^{2}$ Deana Wahyuningrum, ${ }^{3}$ Septoratno Siregar, ${ }^{4}$ Taufan \\ Marhaendrajana \\ ${ }^{1}$ Dosen Teknik Perminyakan Usakti Jakarta, Mahasiawa S3 ITB, Bandung \\ ${ }^{2}$ Dosen Kimia MIPA, ITB, Bandung \\ ${ }^{3,4}$ Dosen Teknik Perminyakan, FTTM, ITB, Bandung \\ e-mail: ${ }^{1}$ rinisetiati_sutrisno@yahoo.com, ${ }^{2}$ deana@chem.itb.ac.id, ${ }^{3}$ septo@tm.itb.ac.id \\ ${ }^{4}$ tmarhaendrajana@tm.itb.ac.id
}

\begin{abstract}
Abstrak. Lignin atau zat kayu adalah salah satu zat komponen penyusun tumbuhan. Komposisi bahan penyusun ini berbeda-beda bergantung jenisnya. Lignin terutama terakumulasi pada batang tumbuhan berbentuk pohon dan semak. Pada batang, lignin berfungsi sebagai bahan pengikat komponen penyusun lainnya, sehingga suatu pohon bisa berdiri tegak (seperti semen pada sebuah batang beton). Lignin merupakan bahan baku pembentuk Lignosulfonat. Lignosulfonat adalah salah satu jenis surfaktan anionik yang dapat digunakan sebagai bahan baku injeksi dalam metoda Injeksi Surfaktan untuk meningkatkan perolehan produksi minyak pada industri perminyakan. Ampas tebu adalah salah satu bahan limbah yang di dalamnya masih terdapat lignin. Ampas tebu adalah hasil samping dari proses ekstraksi cairan tebu. Ampas tebu yang dipergunakan adalah ampas tebu yang telah mengalami proses penggilingan ke lima kali dari proses pembuatan gula. Selama ini ampas tebu digunakan sebagai bahan bakar pabrik gula dan pakan ternak. Dengan proses pemisahan lignin dari ampas tebu ini dapat memberi nilai tambah pemanfaatan ampas tebu sekaligus sebagai alternatif pengolahan ampas tebu sebagai limbah pabrik gula. Salah satu metoda yang digunakan untuk memisahkan lignin dari ampas tebu adalah dengan menggunakan reagen Natrium Hidroksida. Dalam penelitian ini proses hidrolisis lignoselulosa dari ampas tebu menjadi lignin menggunakan variasi konsentrasi natrium hidroksida $(\mathrm{NaOH})$ dan variasi ukuran serbuk ampas tebu. Hasil lignin yang terbentuk dikarakterisasi dengan metode spektroskopi FTIR untuk menentukan gugus-gugus fungsi khas yang terdapat pada struktur lignin dan dibandingkan dengan spektrum FTIR lignin komersial standar sehingga dapat diketahui optimasi pemisahan lignin tersebut.
\end{abstract}

Kata kunci: ampas tebu, lignin, Natrium Hidroksida

\section{Pendahuluan}

Saat ini ampas tebu sebagian besar hanya sebagai bahan bakar pada ketel uap, bahan baku pembuatan kertas, atau sebagai sumber pakan ternak. Pada umumnya, pabrik gula di Indonesia memanfaatkan ampas tebu sebagai bahan bakar bagi pabrik yang bersangkutan, setelah ampas tebu tersebut mengalami proses pengeringan. Potensi bagasse di Indonesia cukup besar, menurut data statistik Indonesia tahun 2002, luas tanaman tebu di Indonesia 395.399,44 ha, yang tersebar di Pulau Sumatera seluas 99.383,8 ha, Pulau Jawa seluas 265.671,82 ha, Pulau Kalimantan seluas 13.970,42 ha, dan Pulau Sulawesi seluas 16.373,4 ha. Diperkirakan setiap ha tanaman tebu mampu menghasilkan 100 ton bagasse. Maka potensi bagasse nasional yang dapat tersedia dari total luas tanaman tebu mencapai 39.539.944 ton per tahun. Inilah yang dijadikan pertimbangan pemilihan ampas tebu untuk diolah karena lahan tebu di Indonesia 
cukup besar, tersebar dari Indonesia bagian Barat sampai Indonesia bagian Timur, mulai dari Sumatera Utara, Palembang, Lampung, P. Jawa, dan Sulawesi, sehingga sumber daya alam telah tersedia (Badan Penelitian \& Pengembangan Pertanian, 2007). Pengembangan perkebunan gula akan mendukung kebutuhan industri gula, yang dalam proses pembuatan gula konsekwensinya akan menghasilkan limbah tebu yang cukup banyak. Jumlah produksi ampas tebu setiap tahunnya cukup melimpah, mudah didapatkan, dan harganya murah. Berdasarkan data dari Pusat Penelitian Perkebunan Gula Indonesia (P3GI), ampas tebu diperoleh sebanyak 32\% dari berat tebu giling atau sekitar 10,2 juta ton/tahun atau permusim giling se-Indonesia (Husin, 2007).

Ampas tebu atau bagasse ini adalah limbah padat industri gula tebu yang mengandung serat lignin, selulosa dan hemiselulosa yang merupakan hasil samping dari proses ekstraksi tanaman tebu. Berdasarkan analisis kimia, rata-rata ampas tebu memiliki komposisi kimia yaitu, abu 3,28 \%, lignin 22,09\%, selulosa 37,65 \%, sari $1,81 \%$, pentosan $27,97 \%$ dan $\mathrm{SiO} 23,01 \%$. Ampas tebu ini dihasilkan sebanyak $32 \%$ dari berat tebu giling. Dengan kandungan ligno-cellulose serta memiliki panjang seratnya antara 1,7 sampai $2 \mathrm{~mm}$ dengan diameter sekitar 20 mikro, ampas tebu sebenarnya bisa dimanfaatkan lagi sebagai bahan baku untuk industri kimia, industri perminyakan, industri kertas, industri kanvas rem, industri jamur dan sebagainya, sehingga ampas tebu ini secara ekonomis pemanfaatannya tidak hanya sebagai sumber energi bahan bakar semata.

Lignin mengisi ruang di dalam dinding sel antara selulosa, hemiselulosa, dan pektin. Lignin berfungsi sebagai bagian penting dalam dsitribusi air di tanaman batang. Polisakarida komponen tanaman dinding sel sangat hidrofilik sehingga permeabel terhadap air, sedangkan lignin lebih hidrofobik. Lignin ada dalam semua tumbuhan vaskular, tapi tidak di bryophyta, mendukung gagasan bahwa fungsi asli lignin dibatasi untuk transportasi air. Lignin sebagai salah satu komponen utama dalam ampas tebu adalah suatu polimer yang komplek dengan bobot molekul tinggi yang tersusun atas unit-unit fenilpropana, yang juga merupakan komponen utama penyusun kayu. Tabel berikut menunjukkan hasil penelitian yang telah dilakukan dimana komponen lignin pada ampas tebu berkisar antara $13-24 \%$.

Tabel 1: Referensi Komposisi Ampas Tebu

\begin{tabular}{|l|c|c|c|c|c|c|}
\hline \multicolumn{1}{|c|}{ Sumber } & Lignin & Selulosa & Hemiselulosa & Pentosa & Silika & Lainnya \\
\hline Arora, 1976 & 13 & 40 & 29 & & 2 & \\
\hline Brady, 2007 & 18 & 45 & & 32 & & 5 \\
\hline Samsuri, 2007 & 24,2 & 52,7 & 20 & & & \\
\hline Bon, 2007 & 21 & 37 & 28 & & & \\
\hline Lacey, 1974 & $13-22$ & $26-34$ & $17-23$ & $23-33$ & & \\
\hline
\end{tabular}

Stuktur molekul lignin sangat berbeda bila dibandingkan dengan polisakarida karena terdiri atas sistem aromatik yang tersusun atas unit-unit fenilpropana. Dalam kayu lunak kandungan lignin lebih banyak bila dibandingkan dengan kayu keras. Beberapa sifat-sifat lignin adalah tidak larut dalam air, berat molekul berkisar antara 2000-15.000, molekul lignin mengandung gugus hidroksil, metoksil dan karboksil dan bila didegradasi oleh basa akan membentuk turunan benzena. Lignin yang kemudian akan menjadi Lignosulfonat merupakan turunan lignin yang mengandung sulfonat yang memiliki gugus hidrofil (gugus sulfonat, fenil hidroksil, dan alkohol hidroksil) dan 
gugus hidrofob (rantai karbon) sehingga termasuk ke dalam kelompok surfaktan anionik. Perkiraan struktur monomer lignin secara sederhana dapat dilihat pada Gambar 1 dibawah ini.

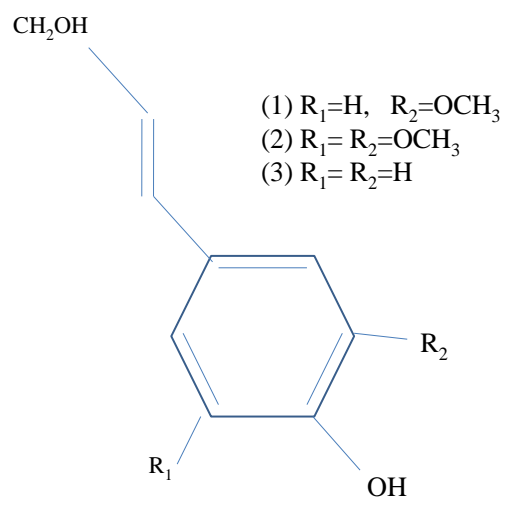

Gambar 1 Perkiraan struktur monomer lignin (Areskogh, 2011)

\section{Metode Penelitian}

\subsection{Bahan dan Alat}

Bahan yang digunakan adalah ampas tebu yang berasal dari pabrik gula, dimana ampas tebu yang digunakan dalam penelitian ini mempunyai kandungan lignin berkisar antara 10,37 \% - 29,46 \% (Balai Besar Pulp \& Kertas, 2013).. Bahan pengisolasi lignin adalah etanol, air, asam sulfat $\left(\mathrm{H}_{2} \mathrm{SO}_{4}\right)$ dan natrium hidroksida $(\mathrm{NaOH})$. Peralatan yang digunakan adalah sieve shaker (pengayak), rangkaian reaktor (labu leher 3 dan kondensor), magnetic stirrer / heating mantle / hot plate, kertas saring dan oven. Proses pemisahan lignin dari ampas tebu menggunakan metode hidrolisis, dengan melakukan refluks ampas tebu dengan etanol, air dan larutan natrium hidroksida.

\subsection{Proses isolasi lignin}

Ampas tebu dari pabrik gula sebelumnya diayak kasar kemudian dioven agar benar-benar kering. Kemudian ampas tebu yang sudah dioven tersebut diayak kembali dengan sieve shaker untuk mendapatkan ukuran serbuk ampas tebu dengan mesh tertentu. Ampas tebu yang telah diayak dengan sieve shaker dengan ukuran mesh tertentu dimasukkan ke dalam labu leher 3 dan direfluks dengan etanol selama 8 jam, kemudian di refluks dengan air selama 2 jam dan selanjutnya direfluks dalam larutan natrium hidroksida selama 4 jam. Campuran reaksi dalam larutan $\mathrm{NaOH}$ tersebut kemudian disaring. Selanjutnya filtrat hasil refluks natrium hidroksida tersebut dinetralkan dengan titrasi asam sulfat pekat $\left(\mathrm{H}_{2} \mathrm{SO}_{4} 98 \%\right)$ hingga $\mathrm{pH}=2$ dan didiamkan minimal 8 jam hingga muncul endapan. Endapan yang dihasilkan kemudian disaring dan dikeringkan dalam oven pada suhu $70{ }^{\circ} \mathrm{C}$. Endapan yang diperoleh ini adalah lignin hasil isolasi dari ampas tebu tersebut. Produk lignin yang dihasilkan beserta lignin komersial (dari Aldrich dan Kraft) kemudian dikarakterisasi strukturnya dengan pengukuran spektrofotometri FTIR. Pengujian dengan spektrofotometri FTIR ini bertujuan untuk menganalisis gugus fungsi yang terkandung dalam lignin hasil hidrolisis tersebut. Berikut skema proses pemisahan lignin dari ampas tebu. 


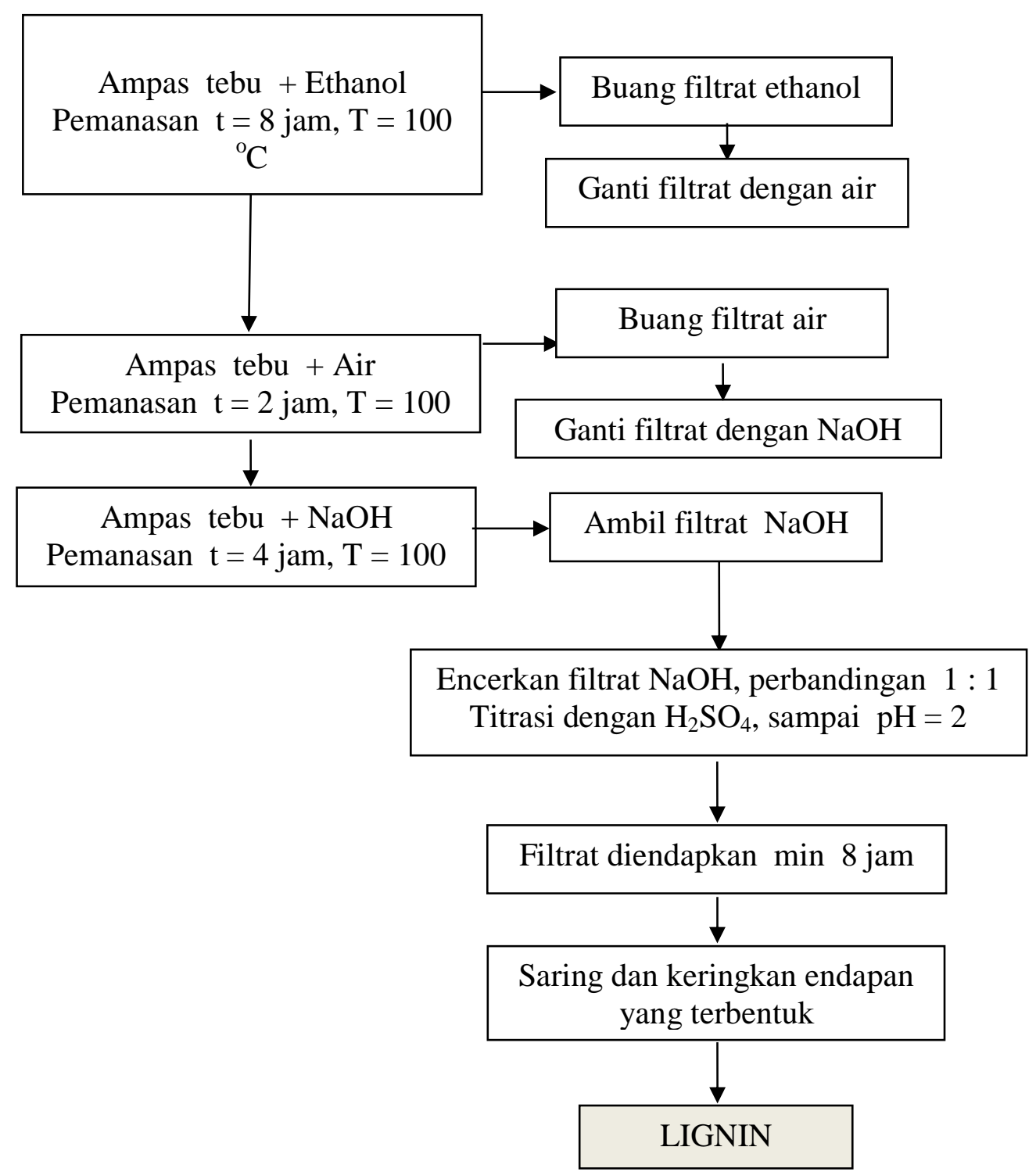

Gambar 2 - Skema Isolasi Lignin

\section{Hasil dan Pembahasan}

Proses isolasi lignin dilakukan dengan variasi mesh ampas tebu yaitu 40 mesh, 60 mesh, 80 mesh dan 100 mesh, serta konsentrasi NaOH yaitu NaOH 2 M, 3 M, 6 M, $8 \mathrm{M}$ dan $10 \mathrm{M}$. Hasil perolehan lignin dapat dilihat pada tabel 2 berikut ini. Pada tabel tersebut terlihat bahwa persentase perolehan lignin terbanyak terjadi pada proses isolasi lignin dengan konsentrasi NaOH $3 \mathrm{M}$ - mesh 40 sebesar 63,36 \%, NaOH $8 \mathrm{M}$ - mesh 60 sebesar 75,73 \% dan NaOH $10 \mathrm{M}$ - mesh 80 sebesar 63,79 $\%$, seperti tampak pada tabel 2 berikut. 
Tabel 2 : Persentase Perolehan Lignin

\begin{tabular}{|c|c|c|c|c|c|}
\hline \multirow[t]{2}{*}{ No. } & \multirow{2}{*}{$\begin{array}{l}\text { Konsentrasi } \\
\mathrm{NaOH}(\mathrm{M})\end{array}$} & \multicolumn{4}{|c|}{ Perolehan Lignin (\%) } \\
\hline & & mesh 40 & mesh 60 & mesh 80 & mesh 100 \\
\hline 1 & 2 & 22,46 & 20,66 & 48,6 & 18 \\
\hline 2 & 3 & 63,36 & 34,36 & 61,8 & 22,22 \\
\hline 3 & 6 & 32,26 & 13,07 & 24,43 & 35,8 \\
\hline 4 & 8 & 66,8 & 75,73 & 38,36 & 24,3 \\
\hline 5 & 10 & 62,85 & 51,8 & 63,79 & 26,1 \\
\hline
\end{tabular}

Tabel 3 - Hasil Spektrofotometri FTIR Lignin Ampas Tebu Pada Variasi Mesh Ampas Tebu dan Konsentrasi $\mathrm{NaOH}$

\begin{tabular}{|c|c|c|c|c|}
\hline No. & Mesh - NaOH & Y1 & Y2 & Y3 \\
\hline 1. & $40-2 \mathrm{M}$ & 2919.7 & 0 & 3421.1 \\
\hline 2. & $60-2 M$ & 2927.41 & 1511.92 & 3451.96 \\
\hline 3. & $80-2 M$ & 0 & 1511.92 & 3544.52 \\
\hline 4. & $40-3 \mathrm{M}$ & 0 & 0 & 3444.24 \\
\hline 5. & $60-3 M$ & 2923.56 & 1508.06 & 3421.1 \\
\hline 6. & $80-3 \mathrm{M}$ & 2919.7 & 1511.92 & 3405.67 \\
\hline 7. & $40-6 \mathrm{M}$ & 2923.56 & 1508.06 & 3459.67 \\
\hline 8. & $60-6 M$ & 2927.41 & 0 & 3417.24 \\
\hline 9. & $80-6 M$ & 2927.41 & 1511.92 & 3413.39 \\
\hline 10. & $40-8 \mathrm{M}$ & 2919.7 & 0 & 3409.53 \\
\hline 11. & $60-8 M$ & 2927.41 & 1508.06 & 3421.1 \\
\hline 12. & $80-8 \mathrm{M}$ & 2931.27 & 1511.92 & 3413.39 \\
\hline 13. & $40-10 \mathrm{M}$ & 2927.41 & 1511.92 & 3382.53 \\
\hline 14. & $60-10 \mathrm{M}$ & 2923.56 & 1511.92 & 3432.67 \\
\hline 15. & $80-10 \mathrm{M}$ & 2915.84 & 1511.92 & 3486.67 \\
\hline
\end{tabular}

$\mathrm{Yi}=$ gugus fungsi $-\mathrm{CH}$ - alifatik aromatik

$\mathrm{Y} 2$ = gugus fungsi $-\mathrm{C}=\mathrm{C}-$ arena

$\mathrm{Y} 3$ = gugus fungsi $\mathrm{O}-\mathrm{H}$ fenolik 


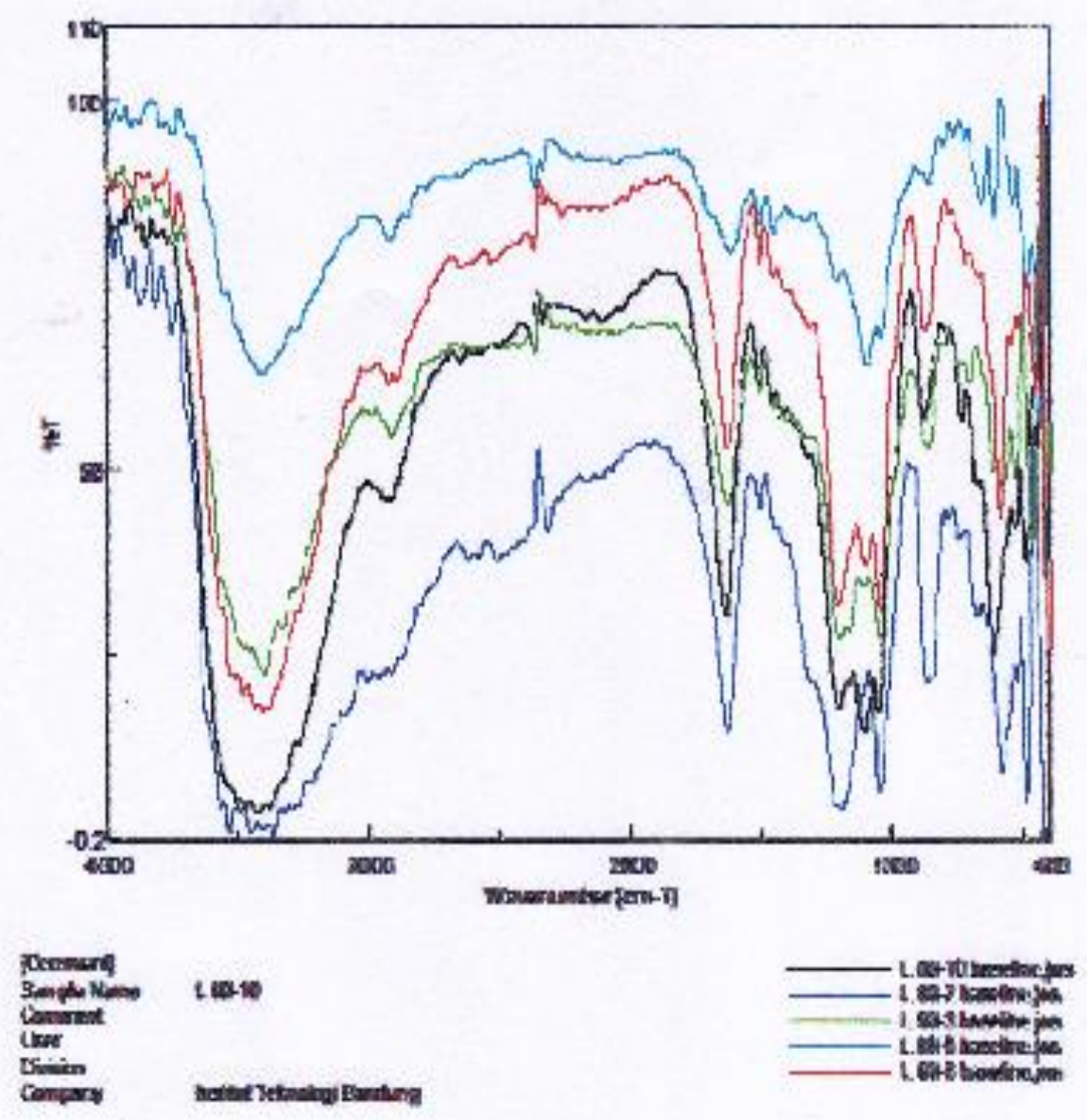

Gambar 3 : Hasil Spektrofotometri FTIR Lignin Ampas Tebu

Berdasarkan hasil persentase lignin yang diperoleh dan hasil uji serapan gugus fungsi lignin tersebut, ternyata tidak semua variasi penelitian mempunyai 3 indikator gugus fungsi pembentuk lignin. Dari 15 variasi hanya 4 variasi yang memenuhi persyaratan, yaitu hasil lignin diatas $60 \%$ dan terdapat komponen pembentuk lignin, yaitu lignin (80-3), lignin (60-8), lignin (40-10) dan lignin (80-10) . Terakhir, hasil lignin tersebut dibandingkan dengan melihat nilai \% Transmitadan diperoleh hasil lignin yang terbaik adalah Lignin (80-3) yaitu lignin ampas tebu yang diproses dengan variasi mesh 80 menggunakan $\mathrm{NaOH} 3 \mathrm{M}$. Lignin (80-3) ini kemudian dibandingkan dengan lignin standar dan lignin komersil yang sudah dipergunakan yaitu dengan lignin komersil Aldrich dan Kraft. Berdasarkan analisis identifikasi puncak-puncak khas pada spektrum FTIR lignin hasil isolasi maupun lignin komersial, ternyata lignin hasil isolasi dari ampas tebu mempunyai beberapa kesamaan gugus fungsi dengan lignin komersial standar dari Aldrich dan Kraft. Beberapa puncak khas tersebut diantaranya adalah gugus ulur $-\mathrm{CH}$ - alifatik dan aromatik dengan bilangan gelombang sekitar $2900 \mathrm{~cm}^{-1}$. Spektrum IR hasil isolasi dari ampas tebu mempunyai puncak khas serapan ulur - $\mathrm{CH}$ alifatik dan aromatik pada bilangan gelombang 2919,7 $\mathrm{cm}^{-1}$, sedangkan serapan puncak khas yang sama lignin komersial Aldrich dan lignin komersial Kraft pada bilangan gelombang 2930,17 $\mathrm{cm}^{-1}$ dan $2926,01 \mathrm{~cm}^{-1}$. Puncak serapan IR ulur untuk gugus fungsi $\mathrm{C}=\mathrm{C}$ - arena dengan bilangan gelombang antara $1500-1600 \mathrm{~cm}^{-1}$, terdapat pada spektrum IR lignin ampas tebu pada bilangan gelombang $1511,92 \mathrm{~cm}^{-1}$, dan muncul 
spektrum IR lignin Aldrich pada $1599,14 \mathrm{~cm}^{-1}$ dan lignin Kraft pada $1614,42 \mathrm{~cm}^{-1}$. Puncak serapan IR untuk gugus fungsi ulur $\mathrm{O}-\mathrm{H}$ fenolik dengan bilangan gelombang 3200 - $3550 \mathrm{~cm}^{-1}$, ditemukan pada spektrum IR lignin ampas tebu pada bilangan gelombang 3405,67 $\mathrm{cm}^{-1}$, spektrum IR lignin Aldrich pada $3436,62 \mathrm{~cm}^{-1}$ dan lignin Kraft pada $3414 \mathrm{~cm}^{1}$. Dengan demikian, spektrum FTIR lignin ampas tebu (80-3) memiliki kesesuaian dengan spektrum FTIR lignin komersial produk Aldrich dan Kraft, terutama untuk puncak-puncak serapan khas fungsi ulur - $\mathrm{CH}$ - alifatik dan aromatik, serapan untuk vibrasi ulur $-\mathrm{C}=\mathrm{C}$ - arena dan serapan vibrasi ulur $\mathrm{O}-\mathrm{H}$ fenolik. Berdasarkan analisa spektrum FTIR dari seluruh variabel penelitian yang digunakan, yaitu ukuran mesh ampas tebu dan konsentrasi $\mathrm{NaOH}$ pada proses isolasi lignin, ternyata lignin dengan nilai rendemen (persentase perolehan) terbaik adalah lignin yang diperoleh dari proses hidrolisis ampas tebu berukuran 80 mesh menggunakan larutan NaOH 3 M (lignin 80-3).

Tabel 4 : Perbandingan Spektrum Panjang Gelombang Lignin Ampas Tebu Dengan Lignin Standar Aldrich dan Kraft

\begin{tabular}{|c|l|l|l|l|l|}
\hline No. & \multicolumn{2}{|c|}{$\begin{array}{c}\text { Indikator komponen } \\
\text { lignin }\end{array}$} & \multicolumn{3}{|c|}{ Panjang gelombang $\mathrm{cm}^{-1}$} \\
\cline { 3 - 6 } & \multicolumn{2}{|c|}{ Standar } & $\begin{array}{c}\text { Lignin } \\
\text { Ampas } \\
\text { Tebu (80-3) }\end{array}$ & Aldrich & Kraft \\
\hline 1. & $\begin{array}{l}\text { Gugus Ulur -CH- alifatik } \\
\text { dan aromatic }\end{array}$ & 2900 & 2919,7 & 2930,17 & 2926,01 \\
\hline 2. & $\begin{array}{l}\text { Gugus fungsi -C=C- } \\
\text { arena }\end{array}$ & $1500-1600$ & 1511,92 & 1599,14 & 1614,42 \\
\hline 3. & $\begin{array}{l}\text { Gugus fungsi O-H } \\
\text { fenolik }\end{array}$ & $3200-3550$ & 3405,67 & 3436,62 & 3414 \\
\hline
\end{tabular}

\section{Kesimpulan}

Berdasarkan evaluasi hasil lignin ampas tebu yang diperoleh dengan menggunakan berbagai variasi mesh serbuk ampas tebu dan konsentrasi reagen $\mathrm{NaOH}$ yang digunakan, serta evaluasi hasil uji spektrum FTIR terhadap sampel lignin tersebut dapat diambil kesimpulan bahwa optimasi pemisahan lignin dari ampas tebu diperoleh pada :

1. Variasi mesh ampas tebu 80 dengan $\mathrm{NaOH} 3 \mathrm{M}$ menghasilkan lignin yang paling baik.

2. Kondisi lignin ampas tebu yang paling baik ini dinyatakan dengan evaluasi spektrum FTIR bahwa lignin ampas tebu tersebut mengandung komponen yang telah sesuai dengan lignin standar Aldrich dan lignin standar Kraft pada gugus fungsi $-\mathrm{CH}$ - aromatik fenolik, gugus alkena $(-\mathrm{C}=\mathrm{C}-)$, ulur $-\mathrm{CH}$ - alifatik dan aromatik, serta gugus $-\mathrm{OH}$ fenolik. 


\section{Ucapan Terima Kasih}

Penelitian ini difasilitasi oleh Ogrindo ITB, Universitas Trisakti dan Dana Riset Desentralisasi 2014 dan Dana Penelitian Unggulan Perguruan Tinggi 2015 Dikti. Terima kasih kepada semua pihak yang telah membantu terlaksananya penelitian ini. Terima kasih juga kepada Panitia Prosiding Seminar Nasional LPPM Unisba atas kerjasamanya sehingga makalah ini dapat disajikan .

\section{Daftar Pustaka}

Amri, A., Zulfansyah, Iwan, M., Suryani, R.,et.al (2008) , Pembuatan Sodium Lignosulfonat Dengan Metode Sulfonasi Langsung Biomasa Pelepah Sawit, Jurusan Teknik Kimia, FT Universitas Riau, Jurnal Sains dan Teknologi, 8(2), 61 - 69.

Areskogh,D., (2011), Structural Modification of Lignosulfonate, KTH Royal Institut of Technology, School of Chemical Science and Engineering, Stockholm

Arora A, Nain L, Gupta JK. (2005), Solid-state fermentation of wood residues by Streptomyces griseus B1, a soil isolate, and solubilisation of lignins. World $\mathrm{J}$ Microbiol Biotechnol.;21:303-308. doi: 10.1007/s11274-004-3827-3

Bon, EPS, Ferara, MA., (2007), Bioetanol Production via Enzymatic Hydrolysis of Cellulosic Biomass, FAO Seminar on The Role of Agricultural Biotechnoligies for Production of Bioenergy in Developing Countries, Rome

Brady, J.W., Himmel, M.E., Ding, S.H., Johnson, D.K., Adney, W.S., Nimlos, M.R.,dan Foust, T.D., (2007), Biomass Recalcitrance Engineering Plants and Enzymes for Biofuels Production. Science 315: $804-807$

Husin, A.A., (2007), Pemanfaatan Limbah untuk Bahan Bangunan, (http://www. Kimpraswil.go.id/balitbang/puskim/homepage20Modul202003/modulc1/MAKALA H 20C1_3.pdf, diakses tanggal 26 Maret 2013

Hepi, A.P, Enggar,H.T., dan Iskandar,L.,. 2009) , Studi Awal Mengenai Pembuatan Surfaktan Dari Ampas Tebu, Jurusan Teknik Kimia, Universitas Diponegoro, Semarang

Heradewi, (2007), Isolasi Lignin lindi Hitam dari Pemasakan Organosolv Serat Tandan Kosong Kelapa Sawit, Tesis Fakultas Teknologi Pertanian, Institut Pertanian Bogor Ismiyati, Suryani,A., Mangunwijaya,D., Machfud dan Hambali,E., Pembuatan Natrium Lignosulfonat Berbahan Dasar Lignin Isolat Tandan Kosong Kelapa Sawit : Identifikasi Dan Uji Kenerjanya Sebagai Bahan Pendispersi, J.Tek.Ind.Pert Vol 19(1),25-29.

Lacey, 1974, Moulding of Sugar Cane Bagasse, Annals of Applied Biology, 76(1) pp 63 $-76$.

Samsuri, 2007, Jurnal Pembuatan Selulosa Bagas Untuk Produksi Etanol Melalui Sakarifikasi dan Fermetasi Serentak Dengan Enzym Xylanase, Makarta Teknologi, 11 